Family Life and Social Control 


\title{
Family Life and Social Control
}

\section{A Sociological Perspective}

\author{
John J. Rodger
}

Consultant Editor: Jo Campling

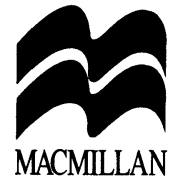


(C) John J. Rodger 1996

All rights reserved. No reproduction, copy or transmission of this publication may be made without written permission.

No paragraph of this publication may be reproduced, copied or transmitted save with written permission or in accordance with the provisions of the Copyright, Designs and Patents Act 1988, or under the terms of any licence permitting limited copying issued by the Copyright Licensing Agency, 90 Tottenham Court Road, London W1P 9HE.

Any person who does any unauthorised act in relation to this publication may be liable to criminal prosecution and civil claims for damages.

First published 1996 by

MACMILLAN PRESS LTD

Houndmills, Basingstoke, Hampshire RG21 6XS

and London

Companies and representatives

throughout the world

ISBN 978-0-333-60464-9

ISBN 978-1-349-24628-1 (eBook)

DOI 10.1007/978-1-349-24628-1

A catalogue record for this book is available from the British Library.

$\begin{array}{llllllllll}10 & 9 & 8 & 7 & 6 & 5 & 4 & 3 & 2 & 1\end{array}$

$\begin{array}{llllllllll}05 & 04 & 03 & 02 & 01 & 00 & 99 & 98 & 97 & 96\end{array}$ 
To John and Agnes Rodger 


\section{Contents}

List of Figures and Tables viii

Acknowledgements ix

Introduction 1

1 Social theory and family life 10

2 Understanding family intervention: theorising professional practice 33

3 Marriage problems and the 'technicians of human relations' $\quad 59$

4 Family structures and the moral politics of caring 91

5 Social policy and family life 116

6 Models of the 'underclass' family 133

7 Dangerous families, public inquiries and child protection 167

8 Concluding observations 198

$\begin{array}{ll}\text { Bibliography } & 206\end{array}$

$\begin{array}{ll}\text { Index } & 221\end{array}$ 


\section{List of figures and tables}

\section{Figure}

4.1 Circumplex model: sixteen types of marital and family systems 98

\section{Tables}

3.1 Divorces granted in the United Kingdom, 1951-87 (in thousands)

5.1 Places in publicly funded childcare services as per cent of all children in the age group 


\section{Acknowledgements}

Some of the ideas contained in the book were incubated in earlier publications. The concepts discussed in Chapter 2 were originally developed in articles published in Sociology, vol. 22, no. 4, 1988, and the British Journal of Social Work, vol. 21, no. 1, 1991, and an earlier version of Chapter 4 appeared as 'Family structures and the moral politics of caring', Sociological Review, vol. 39, no. 4, 1991. I am grateful to Sage Publications for permission to reproduce Figure 4.1 from D. Olson and H. McCubbin, Families: What Makes them Work.

Encouragement to pursue the original idea behind this book came from Jo Campling and I am very grateful to her for the supervisory role she has fulfilled. My colleague Tony Clarke read and commented in detail on the first draft of the book. His critical comments were perceptive and helpful. Whilst he may not recognise fundamental changes in the final version in line with his advice, his observations were valued. Pam Rodger read the final draft and offered detailed comments on it of a substantive and stylistic nature. Her opinions are particularly appreciated.

JOHN J. RODGER 